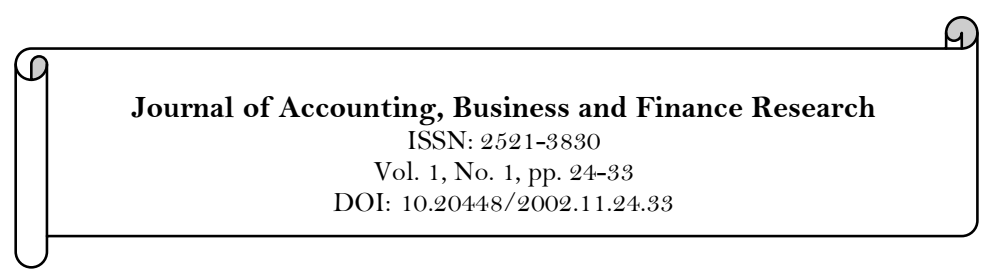

\title{
Analysis of the Responsiveness of Non-Oil Exports to Fiscal and Monetary Policy Actions
}

\author{
Richardson Kojo Edeme ${ }^{1}$ \\ Clifford Nworah Obiayo ${ }^{2}$ \\ 1,22Department of Economics, University of Nigeria, Nsukka-Nigeria.
}

\begin{tabular}{|c|c|}
\hline Abstract & \\
\hline $\begin{array}{l}\text { The paper aims to examine the responsiveness of non-oil exports to } \\
\text { monetary and fiscal policy actions and to ascertain if there is any } \\
\text { significant difference in the response of non-oil exports to fiscal and } \\
\text { monetary policy actions. Adopting the partial determination model, } \\
\text { the paper found that there ismonetary-fiscal policy interaction effect } \\
\text { in the short-run but the effect became undefined in the long-run. It } \\
\text { was also revealed that the response of non-oil exports is dominated } \\
\text { by fiscal policy actions than the responses to monetary policy. Also } \\
\text { monetary policy influences are temporary whereas the fiscal policy } \\
\text { effect seems permanent. In this regard, it will be more appropriate to } \\
\text { place greater reliance on fiscal policy form of stabilization action. The } \\
\text { adoption of mixed monetary-fiscal policy is also recommended. This } \\
\text { is because, mixed monetary-fiscal policy actions operates more } \\
\text { quickly and expand non-oil exports within a short while. Though, } \\
\text { the interaction effect is undefined in the long run, it is appropriate to } \\
\text { stimulate non-oil export in the short-run. }\end{array}$ & $\begin{array}{l}\text { Keywords: } \\
\text { Responsiveness } \\
\text { Monetary policy } \\
\text { Fiscal policy } \\
\text { Non-oil exports } \\
\text { Partial determination model. } \\
\text { JEL Classification: } \\
\text { C31, O23. } \\
\text { Licensed: } \\
\text { This work is licensed under a } \\
\text { Creative Commons Attribution } \\
\text { 4.O License. } \\
\text { Publisher: } \\
\text { Scientific Publishing Institute }\end{array}$ \\
\hline
\end{tabular}

\section{Introduction}

Empirical evidence has revealed that export is required to enhance revenue and economic growth and this has informed the idea of export-led growth thesis. For such, exports are seen as catalyst needed to spur the growth process of the economy (Maneschiöld, 2008; Mishra, 2011; Yelwa \& Diyoke, 2013). In essence, a well developed and functioning export-led economy will provide employment opportunity as higher demand for exports will require more production with the attendant reduction in social cost (Abogan, Akinola, \& Baruwa, 2014).

To stimulate and expand Nigeria's non-oil exports in the post 1970s, fiscal and monetary policies shifted from expansionary to more of restraint and moderation. This shift in policy perhaps led to greater volatility and low non-oil exports in the later periods from 1980s even in the 1990 s when substantial structural and policy reforms were introduced.

The Structural Adjustment Programme (SAP) was further adopted in 1986 and despite its adoption; there has been very little change with respect to the pattern of the government fiscal policy in spite of concerted efforts by the government to control spending in mid-1990s.

The export promotion fiscal policies put in place to encourage non-oil exports among others include the Free Zone law for export processing zone, Export Expansion Grant (EEG) Scheme, Duty Drawback Scheme and Duty Drawback Facilities, which provided refunds of duties/surcharges of raw materials used for manufacturing of products. But fundamental change was witnessed for the case of monetary policy after SAP.

Monetary policy shifted from a direct to an indirect monetary policy management system. These include interest rates policies such as interest rate deregulation; adoption of different monetary policy rates; liberalization of the economy; introduction and the adoption of flexible exchange rate regime, the implementation of Monetary Policy Rate (MPR) to replace the minimum Re-discount Rate (MRR); introduction of the second tier foreign exchange market (SFEM); various export expansion incentive schemes, establishment of the Nigeria Export- Import Bank among others (Abogan et al., 2014).

Even though non-oil exports according to the National Bureau of Statistics (2012) increased from as low as $8.5 \%$ in 2008 to $30.8 \%$ in 2012 , the performance and contribution of the non-oil exports sector compared to the oil export is still very low. 
Ogbonna, Uwajumogu, Chijioke, and Agu (2013) posits that in 1970, non-oil exports as proportion of total export was $42.4 \%$ but fell drastically to $6.2 \%$ in 1989 and increased to $8.5 \%$ in 2008. Annual average total export fell from $10.6 \%$ in the control period of $1970-1985$ to $3.3 \%$ in the $1986-2011$ pro-deregulation eras. Contrary to the expectation of increased non-oil exports, there was an overall decline in non-oil exports below its full potential. Thus, the various separate monetary and fiscal policies in Nigeria seem not to produce the expected improvement in non-oil exports.

For this reason, attention has shifted to the adoption of monetary-fiscal policy mix in a bid to promote non-oil exports and further diversify the economy. Although several studies has been conducted on the effect of monetary and fiscal policy on non-oil exports performance, a major contribution of this study is that we adopted partial determination framework to examine monetary-fiscal policy mix effect on non-oil export and to ascertain if non-oil exports is more predictable to fiscal policy action than monetary policy action. The essence of this is to determine if there is any significant difference in the response of non-oil exports to fiscal and monetary policy actions.

\section{Theoretical and Empirical Literature}

The theoretical link between monetary and fiscal policy mix and non-oil exports is based on the fact that a change in monetary policy and fiscal policy stimulates or dampens economic activities. This relationship is often analyzed using the Hicksian IS-LM framework. The basic tenant of the framework is that the level of economic activity and interest rates is determined by the conjunction of conditions in the aggregate market for goods and services and the market for money.

The IS-LM model is conceived of a general equilibrium defined as the interest rate and income level that generates simultaneous equilibrium in both the product and money markets. Fiscal policy influences the economy through the market for goods and services, while monetary policy works through the money markets (Carlson, 1982; Polito \& Brendon, 2014). Figure 1 below summarizes the IS-LM framework.

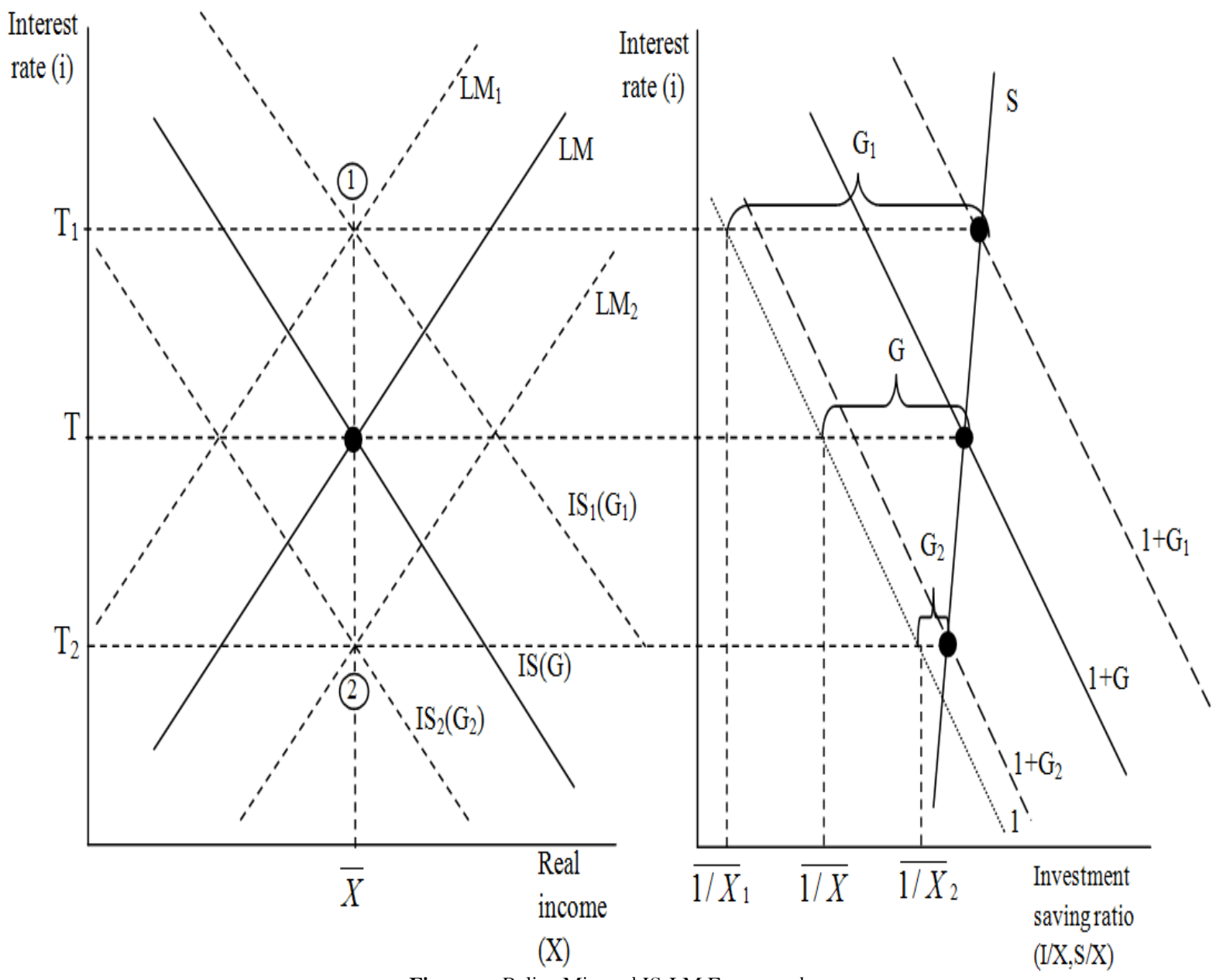

Source: Carlson (1982).

Figure-1. Policy Mix and IS-LM Framework.

Note: 1 implies tight monetary policy $(\mathrm{M} 1<\mathrm{M})$ and easy fiscal Policy $(\mathrm{G} 1>\mathrm{G})$ while 2 means easy monetary policy $(\mathrm{M} 2>\mathrm{M})$ and tight fiscal Policy $(\mathrm{G} 2<\mathrm{G})$ 
In an economy, it is enunciated that real income and interest rates are determined simultaneously by the interaction of the IS and LM curves. This combination is consistent with equilibrium in both the goods and services and money markets. Fiscal policy actions affect equilibrium by shifting the IS curve, while monetary policy actions impact on the LM curve. As a result, a given level of real income can be achieved with different monetary and fiscal policy mix.

The level of real income and interest rates could change over time by a combination of policies in such a way that interest rates are rising or at least being sustained at the high level. The combination of IS and $\mathrm{LM}_{1}$ represents easy fiscal policy and tight monetary policy, and the achievement of an income level with higher interest rate than at the original equilibrium level. In like manner, the $\mathrm{IS}_{2}$ and $\mathrm{LM}_{2}$ interaction indicates tight fiscal policy and easy monetary policy. High interest rate could reduce the rate of private investment (shown in the right hand panel) and therefore reflects slower rate of economic growth in the long run than a set of economic policies that produces low interest rates.

The equilibrium level of output and the interest rate can be shown as follows:

$$
Y^{*}=\llbracket \frac{1}{\partial_{2}}\left(C_{O}-C_{1} \frac{-}{T}+\frac{-}{I}+\frac{-}{G} \cdot \rrbracket-\frac{1}{\beta_{2}}\left(h_{0}-\frac{M}{P}\right) \rrbracket\left[\frac{\beta_{2} \partial_{2}}{\beta_{1} \partial_{2}+\beta_{2}\left(1-C_{1}\left(1-\infty \infty_{1}\right)-\partial_{1}\right)}\right] . .\right.
$$

where $^{*}=$ equilibrium output level, $\mathrm{G}=$ government expenditure

$\bar{G}=$ fixed component of government expenditure, $\mathrm{M}=$ level of nominal money supply chosen by the central bank, $\mathrm{C}_{0}=$ level of consumption affected by factors other than disposable income, such as borrowing, $\mathrm{C}_{1}=$ marginal propensity to consume (the increase in consumption resulting from one unit increase in disposable income).

$\bar{I}=$ constant that computes the effect on investment of any variable other than income and the interest rate

$\bar{T}=$ tax revenue raised through lump-sum taxes

$\mathrm{h}_{\mathrm{o}}=$ level of demand for money independent of income and the interest rate

$\frac{M}{P}=$ real balances

Equation 1 depicts that the policy variables $\mathrm{G}$ and $M$ both increase the equilibrium level of income. Tax policy affects $T^{*}$ negatively through $C_{1}-$ and $C_{1} \infty_{1}$. Here, expansionary fiscal and monetary policies increase the equilibrium level of income. In other words, fiscal and monetary contractions reduce the equilibrium level of income. In the computation of the equilibrium level of the interest rate, the following result is obtained:

$$
i^{*}=\llbracket \frac{1}{\partial_{2}}\left(C_{O}-C_{1} \frac{-}{T}+\frac{-}{I}+\frac{-}{G} \cdot \rrbracket+\frac{1-C_{1}\left(1-\infty_{1}\right)-\partial_{1}}{\beta_{1}}\left(h_{0}-\frac{M}{p}\right) \rrbracket\left[\frac{\beta_{1}}{\beta_{1} \partial_{2}+\beta_{2}\left(1-C_{1}\left(1-\infty_{1}\right)-\partial_{1}\right)}\right] \ldots .\right.
$$

where $i^{*}$ is equilibrium nominal rate and other variables remained as defined above indicating that, fiscal expansions and monetary contractions increase the interest rate whereas fiscal contractions and monetary expansions reduce the interest rate. The effect of fiscal policy, on output and the interest rate, is symmetric for the basis that an expansionary fiscal policy increases both output and the interest rate, while a contractionary fiscal policy reduces both variables.

Whereas, monetary policy has an asymmetric effect on national output and the interest rate: an expansionary monetary policy increases national output while reducing the interest rate, on the contrast a contractionary monetary policy reduces output while increasing the interest rate. The $I S-L M$ model reveals the possibility of the use of fiscal and monetary policies either in isolation, or simultaneously, to influence key macroeconomic variables, such as the interest rate and national output. Since output and export are positively correlated, that is export increases (decreases) when output increases (decreases) fiscal and monetary policy also influence exports (Polito \& Brendon, 2014).

Although Mundell-Fleming developed a similar framework, the difference is that the model assumes an open economy with perfect capital mobility. The model explains the effects of economic policy on a small open economy, and shows how these effects depend on whether the exchange rate is floating or fixed. The model assumes foreign variables and that prices are exogenous determined. Implied is that any differences between real and nominal variables can be ignored. It is therefore assumed that real and nominal interest rates are equal, $r=i$, and real and nominal exchange rates are also equal, $\varepsilon=$ e.

According to the Mundell-Fleming model, an open economy can be described by four separate equations stated below:

$$
\begin{aligned}
& Y=C\left(\begin{array}{c}
Y-T \\
+
\end{array}\right)+I\left(\begin{array}{l}
i \\
-
\end{array}\right)+G+N X\left(\begin{array}{l}
e \\
-
\end{array}\right) . \\
& e=\frac{(1+i) E e^{*}}{\left(1+i^{*}\right)} .
\end{aligned}
$$




$$
\begin{aligned}
& \varepsilon=e P \frac{\Theta P}{P^{*}} \\
& r=i-E \pi
\end{aligned}
$$

The first lemma describes equilibrium in the goods market while the second is the interest rate parity condition which describes equilibrium in the market for foreign exchange, and the third equation represents the definition of the real exchange rate. Equation 6 is the Fisher equation stating the relation between the real interest rate, the nominal interest rate, and expected inflation. The exogenous variables are the interest rate $i$, the fiscal-policy variables, the foreign interest rate $i^{*}$, the expected exchange rate $E \boldsymbol{e}$, domestic and foreign price levels $P$ and $P^{*}$, and inflation expectations $E \pi$. The four equations above explain the equilibrium values for the four endogenous variables which are output $Y$, the nominal exchange rate $e$, the real exchange rate $\varepsilon$, and the real interest rate $r$ (Flodén, 2010).

The functional relationship between both fiscal and monetary policy and non-oil exports has been established. This has motivated series of studies to be conducted on the influence of monetary and fiscal policy variables in the promotion of non-oil exports. A recent study conducted in this regard is Aliyev and Nadirov (2016) who investigated the short and long-run effects of tax revenues on non-oil exports using quarterly data covering 2000Q1-2015Q2.

With autoregressive Distributed Lag Bounds Testing (ARDLBT) Approach to cointegration, the study found significant long-run effects of both budget expenditures and tax revenues but in the short-run, the effect was not significant.

The study by Hasanov (2013a) investigated the role of fiscal policy in the development of Azerbaijan's non-oil sector with special focus on government expenditures using single equation-based, Autoregressive Distributed Lags Bounds Testing (ADLBT) approach and system-based cointegration approach for the period 1998Q4-2012Q3. In terms of elasticity, a positive long run relationship was found between government expenditure and non-oil exports. This finding collaborate Hasanov (2013a) and Hasanov and Alirzayev (2012) for Azerbaijan.

On the role of monetary policy on non-oil exports, studies such as Ismaila and Imoughele (2015), Oriavwote and Eshenake (2015), Akinlo and Adejumo (2014), Shehu (2012) have also been conducted using different fiscal policy variables. Ismaila and Imoughele (2015) used real exchange rate and money supply alongside other control variables to show that effective exchange rate, money supply, and credit to the private sector has a significant impact on non-oil exports. This study is similar to Oriavwote and Eshenake (2015) that also used real exchange rate and found a long run relationship between non-oil exports and real exchange rate.

The parsimonious ECM result also shows that real exchange rate has positive and significant impact on non-oil exports. Also in this category is Akinlo and Adejumo (2014) who used the same monetary policy variable, exchange rate and found that monetary policy has an insignificant impact on non-oil exports. Shehu (2012) used quarterly data for twenty years. The vector co-integration result shows that exchange rate decreased non-oil exports.

The study by Nakibullah and Islam (2007) used the equilibrium approach to fiscal policy to study the effects of government spending on non-oil using Bahrain and US annual data for the period 1977-2004 and notes that the positive multiplier effect of permanent domestic government consumption was substantially neutralized by the negative impact of temporary government spending on non-oil.

The impact of both monetary and fiscal policies on non-oil exports was the focus of the study by Iyoboyi and Na-Allah (2015).

Employing the autoregressive distributed lag framework, the study found that non-oil exports has a long-run equilibrium relationship with economic policies and institutional variables. In specific terms, money supply and exchange rate were found to be positively associated with the determinants of non-oil exports in both the long and short run. Fiscal deficit, interest rate and openness were found to be inversely related to non-oil exports in both the short and long run. The findings also revealed that inflation is negatively related to non -oil exports in the short run, but the reverse was the case in the long run.

In Poland, Alfred, Tomasz, and Anna (2013) examined the transmission channels of monetary and fiscal policy combining both monetary structural vector-autoregression (SVAR) with a fiscal SVAR for small open economy. It was found that a major transmission channel in which non-oil sector can be enhanced are real GDP and real exchange rate.On the contrary, Aliya (2012) found that in an in an emerging open economy, government consumption was unproductive and increases fiscal debt as opposed to government investment, while foreign exchange intervention positively affects net exports but does not stimulate an economy causing inflation.In Nigeria, Chkuigwe and Abili (2008) examined the impact of monetary and fiscal policies on non-oil export from 1974-2003. Using Ordinary Least Squares (OLS) estimation, the study found that interest rate and exchange rate, being proxies for monetary policy, negatively affected non-oil exports. Also budget deficit being proxy fiscal policy has a negative effect on non-oil exports. 


\section{Methodology}

The major aim of this study is to ascertain if non-oil exports can be enhanced with different mixes of monetary and fiscal policies. Second is to establish the responsiveness of non-oil exports to fiscal and monetary policy actions. In our analysis, we included two control variables: degree of openness, and inflation rate. Their inclusion is based on the fact that they have a way of influencing exports Following Ismaila and Imoughele (2015), with some modifications, the functional form of the model is stated as follows:

$$
N O X_{t}=f\left(M P R_{t}, E X R_{t}, G X_{t}, T X_{t}, D O P_{t}, I R_{t}\right)
$$

whereNOX = non-oil export, MPR = monetary policy rate, $\mathrm{EXR}=$ exchange rate, $\mathrm{GX}=$ government total expenditure, $\mathrm{TX}=$ government tax, $\mathrm{DOP}=$ degree of trade openness measured by the ratio of total trade to GDP, IR = inflation rate, $\mathrm{t}=$ time period

In its linear equation form, the model is stated as shown below:

$$
N O X=\alpha_{0}+\alpha_{1} M P R+\alpha_{2} E X R+\alpha_{3} G X+\alpha_{4} T X+\alpha_{5} D O P+\alpha_{6} I R+u_{t} . \quad .
$$

$\pi_{1}<0, \pi_{2}<0, \pi_{3}>0, \pi_{4}<0, \pi_{5}>0$ and $\pi_{6}<0$

Since lag effects contribute to the adjustment process, there is the need to include lagged variables. This allows for greater variety and dynamism in the model. In addition, there is a possible reverse causality that could lead to bias estimates. Just as government expenditure, interest rate, exchange rate affect non-oil exports, non-oil exports could also affect them. One way of resolving this problem is to introduce endogenous independent variables in lags. In this regard, Equation 8 can be re-specified as:

$$
\begin{aligned}
N O X=a_{0}+ & a_{1} N O X_{t-1}+a_{2} M P R+a_{3} M P R_{t-1}+a_{4} E X R+a_{5} E X R_{t-1}+a_{6} G X+a_{7} G X_{t-1} \\
& +a_{8} T X+a_{9} T X_{t-1}+a_{10} D O P+a_{11} D O P_{t-1}+a_{12} I R+a_{13} I R_{t-1} \\
& +u_{t} \cdot \quad \cdot \quad \text { (9) }
\end{aligned}
$$

The analysis of this study uses partial determination model adopted by Carlson (1982) and Anderson and Jordan (1986).

Coefficients of partial determination is used to measure percent of variation of the dependent variable remaining after the variation accounted for by all other variables in the regression has being subtracted from the total variation. In order words, it is a measure of the marginal reduction in the variability in the dependent variable by individual independent variable, when all other variables are in the model. The partial determination model for this study is presented below:

$$
\begin{aligned}
& r_{\text {NOXMPR, axrgXtx }}^{2}=\frac{\operatorname{SSE}\left(M P R \mid E X R_{3} G X_{0} T X_{l} I R\right)}{\operatorname{SSR}\left(E X R_{3} G X_{2} T X_{l} I R\right)} \\
& r_{\text {NOXEXR, mprgxtx }}^{2}=\frac{\operatorname{SSE}\left(E X R \mid M P R_{l} G X_{l} T X_{l} I R\right)}{\operatorname{SSR}\left(M P R_{l} G X_{l} T X_{l} I R\right)} \\
& r_{\text {NOXGE, EXrmprtx }}^{2}=\frac{S S E\left(G X \mid E X R_{2} M P R_{2} T X_{l} I R\right)}{S S R\left(E X R_{l} M P R_{l} T X_{l} I R\right)} \\
& r_{\text {NOXTX, exrgxmpr }}^{2}=\frac{\operatorname{SSE}\left(T X \mid B X R_{l} G X_{l} M P R_{l} I R\right)}{S S R\left(E X R_{l} G X_{a} M P R_{l} I R\right)}
\end{aligned}
$$

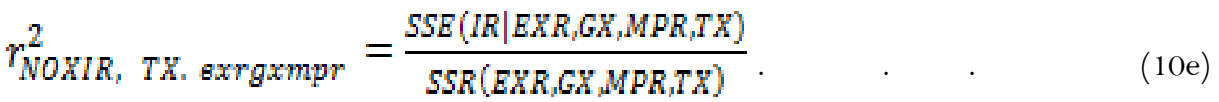

where:

$\operatorname{SSR}(M P R \mid E X R, G X, T X)=$ additional variation explained by MPR when added to a model already containing EXR, GX, TX, and IR

$\operatorname{SSR}(E X R \mid M P R, G X, T X)=$ additional variation explained by EXR when added to a model already containing MPR, GX, TX and IR

$\operatorname{SSR}(G X \mid E X R, M P R, T X)=$ additional variation explained by GX when added to a model already containing EXR, MPR, TX, and IR

$\operatorname{SSR}(T X \mid E X R, G X, M P R)=$ additional variation explained by $\mathrm{TX}$ when added to a model already containing EXR, MPR, GX, and IR 
Note: Variables after $(\mid)$ represent variables already in the model while ESS represents the part of the SSE that is explained by an added group of variables that was not previously explained by the rest.

\section{$S S E=T S S-S S R$}

Equation 10a measures the coefficient of partial determination between NOX and MPR, given that EXR, GX and TX are in the model. It is therefore the proportionate reduction in the variation in non-oil export that is gained after EXR, GX and TX by also including MPR. Similarly, Equation 1ob measures the coefficient of partial determination between NOX and EXR, given that MPR, GX and TX are in the model.

Also, Equation 10c measures the proportionate reduction in the variation in non-oil export remaining after EXR, GX and TX are included in the model that is gained by also including GX. Equation 10d measures the proportionate reduction in the variation in non-oil exports remaining after EXR, GX and MPR are included in the model that is gained by also including TX.

Equation 10e would be adopted to ascertain if there is any significant difference in the response of non-oil exports to fiscal and monetary policy actions. The greater the t-values, the more confidence there is in the estimated regression coefficients, and hence the greater the reliability of the estimated change in non-oil exports resulting from a change in the fiscal policy variable. The data for this study is a quarterly time series sourced from Central bank of Nigeria (CBN) statistical bulletins, 2009 and 2014. The Econometric software for estimation is STATA 12

\section{Results and Discussion} below.

Firstly, the descriptive statistics of the variables was examined and the result is presented in Table 1

Table-1. Summary Statistics.

\begin{tabular}{l|l|l|l|l}
\hline \multicolumn{1}{c|}{ Variables } & Mean & Standard Deviation & Minimum & Maximum \\
\hline NOX & 138176.1 & 286957.4 & 203.2 & 1130171 \\
\hline EXR & 49.9264 & 60.80556 & 0.5464 & 160.7228 \\
\hline IR & 18.85167 & 16.42639 & 0.2 & 76.8 \\
\hline MPR & 10.78797 & 5.017758 & 3.2 & 26 \\
\hline GX & 957721 & 1512834 & 635.121 & 5185318 \\
\hline TX & 472544.5 & 815115.5 & 421.5 & 3275121 \\
\hline DOP & 7.363778 & 10.66566 & 0.07 & 58.55 \\
\hline
\end{tabular}

The mean values of NOX, EXR, IR, MPR and GX are respectively 138176.1, 49.9264, 18.85167, 10.78797, and 957721. While the mean values of TX and DOP are respectively 472544.5 and 7.363778. It is revealed that the values of IR and MPR are close and cantered around their respective mean values, as indicated by the small standard deviation values (less than the mean values). On the other hand, the values of NOX, EXR, GX, TX, and DOP are farther away from their respective mean values. All the minimum values of the variables are less than the mean values respectively while the maximum values are all greater than their respective mean values.

\subsection{Unit Root Test}

Time series data in many cases possess unit root at it level form and regression results from such data could be misleading. Thus, unit root test was carried out using the Augmented Dickey-Fuller and Philips Perron tests and the results are reported in Tables 2 below.

Table-2. Augmented Dickey - Fuller and Philips-Perron Unit Root Test Result

\begin{tabular}{|c|c|c|c|c|c|c|}
\hline \multirow[t]{2}{*}{ Variable } & \multicolumn{2}{|c|}{ ADF Result } & \multicolumn{2}{|c|}{ P-P Result } & \multirow[t]{2}{*}{ Lag order } & \multirow[t]{2}{*}{$\sim \mathbf{I}(\mathbf{d})$} \\
\hline & Level & $1^{\text {st }}$ Difference & Level & $1^{\text {st }}$ Difference & & \\
\hline $\mathrm{NOX}$ & -0.536 & $-5.941^{*}$ & -1.950 & $-5.270^{*}$ & 2 & $\mathrm{I}(1)$ \\
\hline EXR & -0.138 & $-5.652^{*}$ & -0.921 & $-5.217 *$ & 2 & $\mathrm{I}(1)$ \\
\hline IR & -1.286 & $-7.024 *$ & -2.771 & $-6.078^{*}$ & 2 & $\mathrm{I}(1)$ \\
\hline MPR & -1.615 & $-7.206^{*}$ & -1.862 & $-6.389^{*}$ & 2 & $\mathrm{I}(1)$ \\
\hline GX & -0.641 & $-4.809^{*}$ & -2.565 & $-4.444^{*}$ & 2 & $\mathrm{I}(1)$ \\
\hline TX & -0.013 & $-5.308^{*}$ & -1.615 & $-4.930^{*}$ & 2 & $\mathrm{I}(1)$ \\
\hline DOP & -1.631 & $-9.219 *$ & -1.384 & $-7.074 *$ & 2 & $\mathrm{I}(1)$ \\
\hline
\end{tabular}

Note: * denotes significance at $5 \%$ and the rejection of the null hypothesis of presence of unit root. The optimal lag lengths were chosen according to Akaike's final Prediction Error (FPE), and Akaike's information criterions. The ADF critical value at levels is -1.654 while at 1 st difference is -1.654 . The PhilipsPerron critical value at levels and 1 st difference on the other hand is 2.885 . 
The Augmented Dickey Fuller test result reveals that none of the variables is stationary at its level form. Therefore, the variables were differenced once and tested again in a model with drift and lag length of 2 . The test result at first difference shows that all the variables are significant. The respective Augmented Dickey Fuller statistics at the $1^{\text {st }}$ difference are all greater than the 5 percent critical value. Thus, we say that the variables are all integrated of order one. Similarly, the Philips Perron test also revealed that the variables are not stationary at the level form at 5 percent. The null hypothesis that the variables have unit root is for this reason rejected at the 5 percent significant level. This result supports the result of the Augmented Dickey Fuller test that the variables are all stationary at $1^{\text {st }}$ difference.

\subsection{Regression Result}

Table-3. Impact of monetary and fiscal policies on non-oil exports.

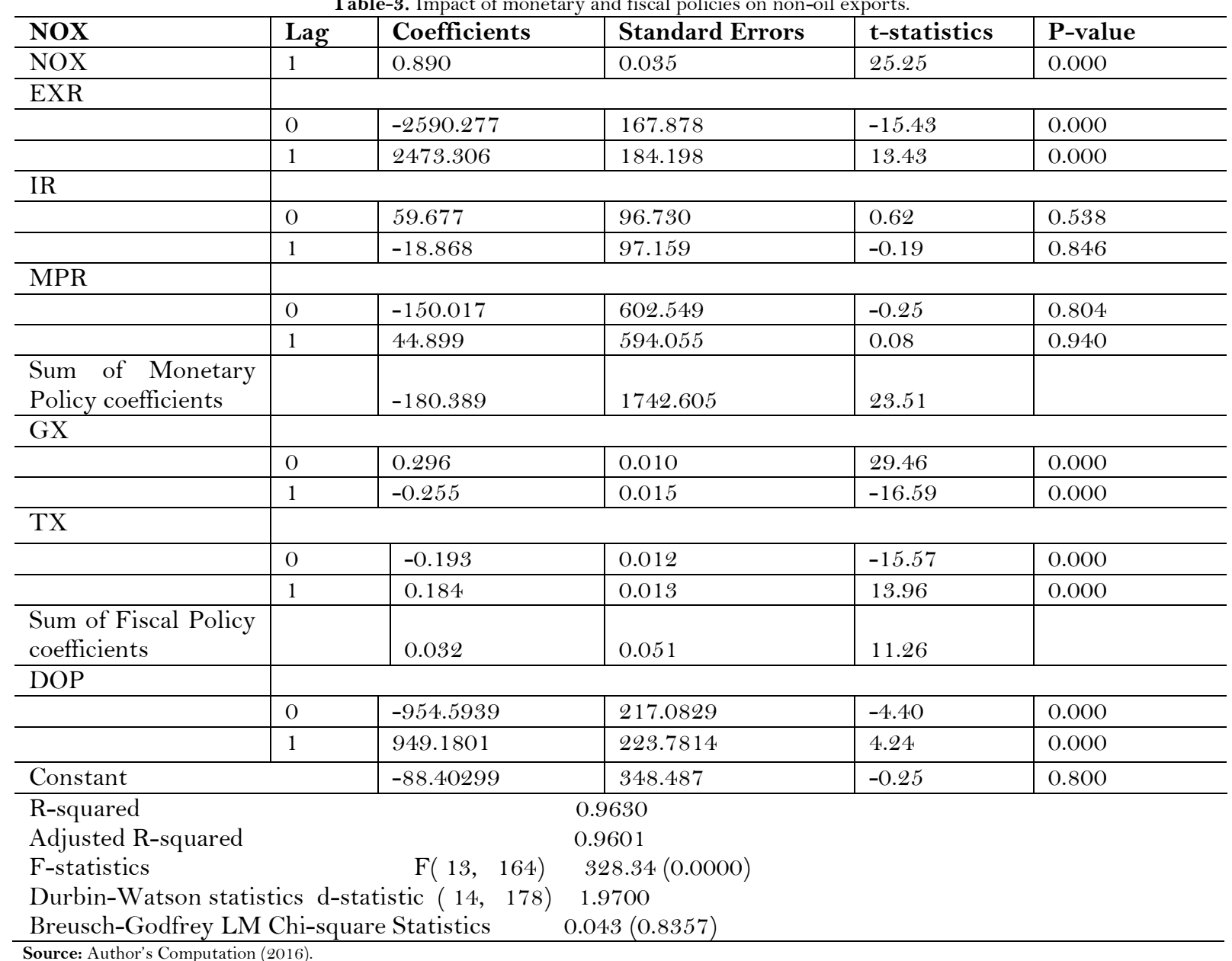

Source: Author's Computation (2016).

From the above result and based on Equations 10a - 10e the monetary-fiscal policy interaction effect on non-oil exports, the partial coefficients of determination are computed as follows.

$$
\begin{aligned}
r_{\text {NOXMPR, exrgxtx }}^{2}= & \frac{\operatorname{SSE}(M P R \mid E X R, G X, T X, I R)}{S S R(E X R, G X, T X, I R)}=\frac{0.02}{1.49}=0.01 \\
r_{\text {NOXEXR. mprgxtx }}^{2}= & \frac{S S E(E X R \mid M P R, G X, T X, I R)}{S S R(M P R, G X, T X, I R)} \frac{0.58}{2.05}=0.28 \\
r_{\text {NOXGE, exrmprtx }}^{2}= & \frac{S S E(G X \mid E X R, M P R, T X, I R)}{S S R(E X R, M P R, T X, I R)} \frac{0.59}{1.91}=0.31 \\
r_{\text {NOXTX, exrgxmpr }}^{2}= & \frac{S S E(T X \mid E X R, G X, M P R, I R)}{S S R(E X R, G X, M P R, I R)} \frac{0.14}{1.61}=0.09
\end{aligned}
$$




$$
\begin{aligned}
& r_{\text {NOXIR, TX, exrgxmpr }}^{2}=\frac{\operatorname{SSE}(I R \mid E X R, G X, M P R, T X)}{\operatorname{SSR}(E X R, G X, M P R, T X)} \frac{0.02}{1.49}=0.01 \\
& r_{\text {NOXMPR, exrgxtx }}^{2}=\frac{\operatorname{SSE}\left(M P R_{t-1} \mid E X R, G X, T X, I R, M P R\right)}{\operatorname{SSR}(E X R, G X, T X, I R, M P R)}=\frac{0.00}{1.47}=0.00 \\
& r_{\text {NOXMPR. exrgxtx }}^{2}=\frac{\operatorname{SSE}\left(E X R_{t-1} \mid E X R, G X, T X, I R, M P R\right)}{\operatorname{SSR}(E X R, G X, T X, I R, M P R)}=\frac{0.03}{1.47}=0.02 \\
& r_{\text {NOXMPR, axrgxts }}^{2}=\frac{\operatorname{SSE}\left(I R_{t-1} \mid E X R, G X, T X, I R, M P R\right)}{S S R(E X R, G X, T X, I R, M P R)}=\frac{0.00}{1.47}=0.00 \\
& r_{\text {NOXMPR, exrgxtx }}^{2}=\frac{\operatorname{SSE}\left(G X_{t-1} \mid E X R, G X, T X, I R, M P R\right)}{\operatorname{SSR}(E X R, G X, T X, I R, M P R)}=\frac{0.02}{1.47}=0.01 \\
& r_{\text {NOXMPR, exrgxtx }}^{2}=\frac{\operatorname{SSE}\left(\mathrm{TX}_{t-1} \mid E X R, G X, T X, I R, M P R\right)}{\operatorname{SSR}(E X R, G X, T X, I R, M P R)}=\frac{0.08}{1.47}=0.05
\end{aligned}
$$

\begin{tabular}{|c|c|c|c|c|c|c|c|}
\hline \multirow[b]{2}{*}{ Period } & \multicolumn{3}{|c|}{$\begin{array}{l}\text { Monetary } \\
\text { Variables }\end{array}$} & \multicolumn{2}{|c|}{$\begin{array}{ll}\text { Fiscal } & \text { Policy } \\
\text { Variables } & \end{array}$} & \multirow[t]{2}{*}{$\begin{array}{l}\text { Policy interaction } \\
\text { Effect }\end{array}$} & \\
\hline & EXR & IR & MPR & GX & $\mathrm{TX}$ & & \\
\hline t & 0.28 & 0.01 & 0.01 & 0.31 & 0.09 & 0.10 & $\begin{array}{l}\text { Interaction } \\
\text { effect defined }\end{array}$ \\
\hline$t-1$ & 0.02 & 0.00 & 0.00 & 0.01 & 0.05 & - & $\begin{array}{l}\text { Interaction } \\
\text { effect } \\
\text { undefined }\end{array}$ \\
\hline Sum & 0.3 & 0.01 & 0.01 & 0.32 & 0.14 & 0.14 & $\begin{array}{l}\text { Interaction } \\
\text { effect defined }\end{array}$ \\
\hline
\end{tabular}

From the coefficients, the policy mix effects of monetary and fiscal policy is presented in Table 4 below

For the quarterly data, the partial determination coefficient for government expenditure is greater than that of exchange rate, interest rate and monetary policy rate. With regard to government tax revenue, the coefficient is less than the exchange rate but greater than interest rate and monetary policy rate. Since the fiscal policy partial coefficients of determination are larger than monetary policy actions, then, there is monetary-fiscal policy mixed effect on non-oil exports which is found to be $10 \%$. However for the subsequent quarter, the coefficient for exchange rate is 0.02 while those of interest rate and monetary policy rate are 0.00 and 0.00 respectively. Since the partial coefficients of determination of the fiscal policy variables (IR and MPR) of the first one quarter are less than 0.005 , then the test for the first one quarter is said to be undefined.

That is, the presence or absence of interaction effect of monetary and fiscal policies on non-oil exports in Nigeria cannot be determined in the first lag. In general, it can be inferred that monetary-fiscal policy interaction effect of monetary and fiscal policies on non-oil exports exists in the short-run but the presence or absence of interaction effect cannot really be determined in the long run.

To ascertain if there is any significant difference in the response of non-oil exports to fiscal and monetary policy actions, the result is presented in Table 5 below.

Table-5. Measurement of the Response of Non-oil Exports to Monetary and Fiscal Policy actions.

\begin{tabular}{l|l|l|l|l|l}
\hline & \multicolumn{4}{|l}{ Monetary Policy Variables } & \multicolumn{2}{l}{ Fiscal Policy Variables } \\
\hline Period & EXR & IR & MPR & GX & TX \\
\hline $\mathrm{T}$ & -15.43 & 0.62 & -0.25 & 29.46 & -15.57 \\
\hline $\mathrm{t}-1$ & 13.43 & -0.19 & 0.08 & -16.59 & 13.96 \\
\hline Sum & -2.00 & 0.43 & -0.17 & 12.87 & -1.61 \\
\hline
\end{tabular}


A perusal of Table 5 shows larger t-values for the fiscal policy variables than the monetary policy variables in absolute terms, even in the first quarter after a change. Also, the t-value for the sum of the coefficient for government tax revenue is larger while those for interest rate and monetary policy rate are not significantly different from zero.

Since the coefficients relative to their standard errors in relation to changes in fiscal policy to changes in non-oil exports are greater than the corresponding measures for changes in monetary policy, it implies that non-oil exports is more responsive to fiscal policy actions than monetary policy actions. A major policy implication of this is that in the promotion of non-oil exports, the impact of a change in fiscal policy is more pronounced than that of monetary policy.

\section{Conclusion}

The analyses of this paper have revealed that the Hicksian IS-LM framework is not a sufficient approach in examining monetary-fiscal policy mix effect. Perhaps an appropriate approach is that the lag effects of monetary-fiscal policy influences must be taken into account.

The partial determination framework adopted by this study reveals that there is both short-run and long-run impact of fiscal policy on non-oil exports, but monetary policy has no long run impact. Monetary policy variable found to be significant in accentuating non-oil exports is the exchange rate while government expenditure and government tax are significant fiscal policy instruments that has influence non-oil exports. The response of non-oil exports is dominated by fiscal policy actions than the response to monetary policy influence.

Also, monetary policy influences are temporary, whereas the fiscal policy effect is permanent. In addition, monetary-fiscal policy interaction actions operate more quickly but the effect dissipates after a year.

The finding that non-oil exports is more response to fiscal policy actions than monetary policy action strongly suggests that it will be more appropriate to place greater reliance on the latter form of stabilization action.

Considering the current economic recession and the agenda of the federal government to diversify the economy and to boost non-oil exports, the study recommends the adoption of mixed monetary-fiscal policy. This is because, monetary-fiscal policy actions operates more quickly; and could possibly take us out of the recession and expand non-oil exports within a short while, though, the interaction effect is undefined in the long run.

\section{References}

Abogan, O., Akinola, E., \& Baruwa, O. (2014). Non-oil export and economic growth in Nigeria. Journal of Research in Economics and International Finance, 3(1), 1-11.

Akinlo, A. E., \& Adejumo, V. A. (2014). Exchange rate volatility and non-oil exports in Nigeria: 1986-2008. International Business and Management, 9(2), 70-79.

Alfred, A. H., Tomasz, J., \& Anna, S. (2013). Combining monetary and fiscal policy in an SVAR for a small open economy. University of Otago Economics Discussion Papers No. 1313.

Aliya, A. (2012). Monetary and fiscal policy interactives in an emerging open economy exposed to sudden stops shock: A DSGE approach. FIW Working Paper $\mathrm{N}^{\circ} 94$.

Aliyev, K., \& Nadirov, O. (2016). How fiscal policy affects non-oil economic performance in Azerbaijan? Academic Journal of Economic Studies, 2(3), 11-29.

Anderson, L. C., \& Jordan, J. L. (1986). Monetary and fiscal actions: A test of their relative importance in economic stabilization. Federal Reserve Bank of St. Louis Revierw, 80, 29-45.

Carlson, K. M. (1982). The mix of monetary and fiscal policies: Conventional wisdom vs. empirical reality. Federal Reserve Bank of St. Louis Review. Retrieved from https://research.stlouisfed.org/publications/review/1982/10/01/themix-of- monetary-and-fiscal-policies-conventional-wisdom-vs-empirical-reality/.

Chkuigwe, E. C., \& Abili, I. D. (2008). An econometric analysis of the impact of monetary and fiscal policies on non-oil exports in Nigeria: 1974-2003. African Economic and Business Review, 6(2), 59-72.

Flodén, M. (2010). The open economy revisited: The Mundell-Flemingmodel and the exchange-rate regime. Stockholm School of Economics.

Hasanov, F. (2013a). The role of the fiscal policy in the development of the non-oil sector in Azerbaijan. Hazar Raporu, 4, $162-173$.

Hasanov, F., \& Alirzayev, E. (2012). The government spending, FDIs and the nonoil sector of the oil-exporting economy. Manuscript from the Center for Socio-Economic Research, Qafqaz University.

Ismaila, M., \& Imoughele, L. E. (2015). Macroeconomic determinants of economic growth in Nigeria: A co-integration approach. International Journal of Academic Research in Economics and Management Sciences, 4(1), 34 - 46.

Iyoboyi, M., \& Na-Allah, A. (2015). Policy, institutions and non-oil exports: Evidence from Nigeria. International Journal of Economics and Finance, 7(11), $10-23$.

Maneschiöld, P. O. (2008). A note on the export-led growth hypothesis: a time series approach. Economics Notebooks, 45(132), 293-302.

Mishra, P. K. (2011). The dynamics of relationship between export and economic growth in India. International Journal of Economic Sciences and Applied Research, 4(2), 53-70.

Nakibullah, A., \& Islam, F. (2007). Effect of government spending on non-oil GDP of Bahrain. School of Business, Finance and Economics Department Working Paper No. 07-07, Utah Valley State College. 
Ogbonna, Uwajumogu, Chijioke, \& Agu. (2013). Economic globalization: Its impact on the growth of non-oil supply in Nigeria. Journal of Economics and Sustainable Development, 4(7), 66-67.

Oriavwote, V. E., \& Eshenake, S. J. (2015). Real effective exchange rate and non-oil exports performance in Nigeria: An empirical reflection. International Journal of Business, Humanities and Technology, 5(6), 55-61.

Polito, V., \& Brendon, C. (2014). Macroeconomics. United Kingdom: University of London International Programmes.

Shehu, A. A. (2012). Impact of foreign exchange volatility on imports: A case of Nigerian foreign exchange market (1987-2008). Paper presented at the Proceedings of the 7 th International Conference on Innovation \& Management, Lagos.

Yelwa, M., \& Diyoke, K. O. (2013). An empirical investigation of export-led growth amongst some selected ECOWAS countries: An alternative to FDI? European Journal of Management Sciences and Economics, 1(1), 30-38. 